\title{
Wsparcie i płeć psychologiczna kobiet i mężczyzn - raport z badań
}

KEY WORDS

psychological gender, support, stabilisation missions

\begin{abstract}
Molesztak Aldona, Wsparcie i płeć psychologiczna kobiet i mężczyzn - raport z badań [Support and Psychological Gender of Men and Women - a Research Report]. Kultura - Społeczeństwo - Edukacja nr 2(10) 2016, Poznań 2016, pp. 151-162, Adam Mickiewicz University Press. ISSN 2300-0422. DOI 10.14746/kse.2016.10.12.

The aim of the research was to determine the psychological gender against the background of a partner's support and the spouse's workplace. The research involved a group of 503 married women and men, including 354 professional soldiers - of who 152 have participated in military missions and 202 work in Poland. The research included also 149 women - 94 wives of soldiers participating in missions and 55 women in relationship with soldiers doing their job in Poland. To collect the data for research the nonprobability snowball and purposive sampling methods have been applied. The research was conducted in 2013. The respondents, in majority showing androgynous characteristics, perceive the support on the part of their families as average or very low. Substantial differences as to the psychological gender and support have been observed in the group of soldiers doing their service in their home country. The feminine men and people with unspecified gender identity seem to receive the lowest support, while the androgynous people and male men experience the highest one. Interesting dispersion of results has been observed - the lowest for the group of feminine men, the highest for the androgynous ones.
\end{abstract}

\section{Wstęp}

Świat współczesny zmienia się dynamicznie i szybko. Przekształcenia są następstwem między innymi rozwoju techniki. Te są dostrzegane najwcześniej. Wpływają one na przeobrażenia w obszarze demograficznym, społecznym i ekonomicznym. Wśród tradycyjnych zagadnień demograficznych, obejmujących między 
innymi przyrost naturalny, migrację i strukturę społeczną, pojawiają się nowe zagadnienia. Takim nowym obszarem zainteresowania $w$ demografii są zmiany obejmujące rodzinę. Ze społecznego punktu widzenia analizuje się strukturę rodziny, wsparcie i jej przemiany, a ze względu ekonomicznego analizie poddawane są zasoby rodziny oraz różnice występujące $\mathrm{w}$ wynagrodzeniu pomiędzy kobietami i mężczyznami.

Połączenie życia rodzinnego z pracą zawodową kobiet i rozwój ich zainteresowań przekształca dotychczasowy wizerunek. Następuje współczesne przełamywanie stereotypów, chociaż są one obecne w codziennym funkcjonowaniu kobiet. Trudno nie wskazać mechanizmów występujących w podejmowanej przez nie pracy zawodowej, takich jak: „ruchome schody”, „szklany sufit” czy „lepka podłoga". Na tradycyjne spostrzeganie płci wskazują badania D. Pankowskiej, M. Chomczyńskiej-Rubachy (2014), natomiast o kreowaniu nowego obrazu świadczą badania przeprowadzone przez E. Mandal (1994). Podkreślają zmianę wśród wykształconej grupy kobiet, które realizują jedną z ról społecznych. Badania ekonomiczne wykazały, że współczesne kobiety w większości zajmują tę samą pozycję ekonomiczną, jaką zajmowały w latach sześćdziesiątych ubiegłego wieku. Wyjątek stanowią młode, wykształcone, niezamężne kobiety (Bem, 2000: 169).

Celem niniejszego artykułu jest analiza wsparcia kobiet i mężczyzn, uwzględniająca ich płeć psychologiczną. Artykuł składa się z trzech części: teoretycznej, opisującej metody badań i analizującej wyniki. W pierwszej rozpatrywana jest podjęta $\mathrm{w}$ artykule tematyka wsparcia i płci psychologicznej. Część metodologiczna obejmuje cel badań, pytanie badawcze, metody, dobór próby. Raport $\mathrm{z}$ badań własnych zawiera analizę otrzymanych wyników oraz ich interpretację.

Sformułowane stwierdzenia $\mathrm{z}$ dotychczasowych dyskusji naukowych stały się podstawą odpowiedzi na pytanie o wsparcie kobiet w rodzinie na tle płci psychologicznej we współczesnym stechnologizowanym świecie. Wyjaśnienie tak sformułowanego celu kobiecości i męskości nastąpi poprzez posłużenie się teorią schematów płciowych Sandry L. Bem.

\section{Płeć psychologiczna i jej implikacje}

Transformacja w rodzinach oraz poprawa wskaźników umieralności, powodująca wydłużenie się życia ludzkiego, ma wpływ na przeobrażenia procesu odtwarzania pokoleń i jednocześnie wiąże ten proces ze zmianą ról społecznych (Kotowska, Jóźwiak, 2011). Zachodzące $\mathrm{w}$ społeczeństwie przemiany rewidują poglądy w zakresie tradycyjnych ról kobiecych i męskich. Są to kategorie ujmowane bardzo szeroko zarówno w kontekście indywidualnym, jak i społeczno-kulturowym. 
Historyczna analiza roli kobiety i mężczyzny w życiu dowodzi, że były one nie tylko rozdzielone w wielu kulturach, ale także odmienne. Kobieta i mężczyzna przygotowywani byli do specyficznych dla siebie działań w określonych sferach życia. Wynika to z faktu, że kobiety i mężczyźni różnią się od siebie cechami fizycznymi, ale także niejednokrotnie zachowują się w inny sposób. Różnice wynikają nie tylko z biologii, ale są też efektem uspołecznienia (Zimbardo, 2004: 184). Przysługuje im odgrywanie innych, zmienionych ról w społeczeństwie zmieniającym się kulturowo i cywilizacyjnie. H. Machel stwierdza, że przez tysiąclecia wiele kultur dochodziło do symbolicznego przesunięcia, zmiany odległości pomiędzy światem kobiet a mężczyzn. „W mniejszym lub większym stopniu, ale wszystkie zmierzały w tym samym kierunku: oba światy - kobiet i mężczyzn - zbliżały się do siebie, role upodabniały się, zachowania unifikowały, reguły i wzorce społeczne były dla obu płci bardziej zbieżne” (Machel, 2012: 11). Dowodzi tego fakt, że współczesna rzeczywistość wymaga od kobiet i mężczyzn podejmowania decyzji i zachowań, które nie są zgodne z przypisanymi im tradycyjnymi rolami.

Dotychczasowe, tradycyjne pojęcia męskości i kobiecości są w obecnych czasach zasadniczo zachwiane. Żyjemy w okresie gwałtownych przeobrażeń nie tylko społecznych, lecz także moralnych, etycznych i seksualnych. Pojęcie płci psychologicznej człowieka $\mathrm{w}$ tym kontekście rozumiane jest jako spontaniczna gotowość do posługiwania się wymiarem płci w odniesieniu do siebie i świata, która także uległa w ostatnim czasie przemianie. Do lat 60. sądzono, że człowiek może być albo męski, albo kobiecy. Wspomniane poglądy zostały zweryfikowane przez S.L. Bem (1977), która stwierdziła, że kobiecość i męskość stanowią dwa osobowościowe wymiary. Odrzuciła jednowymiarową i bipolarną koncepcję męskości i kobiecości, przyjęła koncepcję dwóch niezależnych względem siebie czynników ortogonalnych (Bem, 2000).

W literaturze występuje rozróżnienie na płeć biologiczną i płeć psychologiczną. Płeć biologiczna (sex) dotyczy właściwości biologicznych odróżniających osobniki męskie od żeńskich. Atrybutem biologicznym są różne funkcje reprodukcyjne kobiet i mężczyzn, inne hormony oraz anatomia. Są one biologicznie zdeterminowane i niezależne od czynników społecznych. Natomiast płeć psychologiczna (gender) ,jest zjawiskiem wyuczonym, związanym z odmiennością zachowań i postaw zwykle cechujących osoby o odmiennej płci biologicznej. Kultury różnią się stopniem, w jakim płeć psychologiczna wiąże się ze zróżnicowaniem codziennych czynności i zakresem tolerancji na zachowania spostrzegane jako niezgodne z własną płcią" (Zimbardo, 2004: 184). Płeć psychologiczna jest układem cech psychicznych związanych z płcią, takich jak kobiecość czy męskość. Cechy kształtują się w jednostce od wczesnego dzieciństwa, w wyniku jej uczestnictwa w życiu społecznym. Zatem płeć psychologiczna tworzy się w pierwszych 
latach życia pod wpływem wielu czynników wewnętrznych i zewnętrznych. $\mathrm{Z}$ tego względu charakterystyczny wpływ na kształtowanie stosunku do stereotypów ma w dzieciństwie rodzina. Formowanie płci poprzez modelowanie otwartości na świat, emocjonalności czy postrzegania seksualności może stać się podstawą międzypokoleniowej transmisji tych schematów (Sanocka, 2012: 4).

Dotychczasowe badania obejmujące wpływ płci psychologicznej na funkcjonowanie jednostki potwierdzają, że ma ona istotne znaczenie $\mathrm{w}$ sposobach zachowania się w różnych sytuacjach życiowych. Dla analizy płci psychologicznej istotne jest określenie roli płciowej i roli społecznej. Obydwa pojęcia występują zamiennie. Rola płciowa to rola społeczna. P. Zimbardo wyróżnia role społeczne (gender roles) rozumiane jako wzory postępowania uważane za prawidłowe dla kobiet i mężczyzn w określonym społeczeństwie (Zimbardo, 2004: 184). Rola płciowa pojmowana jest jako zespół cech i zachowań, które uważa się w jakieś konkretnej kulturze za właściwe jednej płci. „Pełnienie przez człowieka określonej roli należy ujmować dynamicznie, gdyż jej przejawy unaoczniają się zależnie od kontekstu sytuacyjnego; symptomami społecznymi podejmowanej roli płciowej stają się zaś bardzo różnorodne reakcje (ekspresje), w tym także reakcje seksualne" (Dulko, 2003: 8). Rola społeczna obejmuje zestaw zachowań jednostki, dzięki któremu uzyskujemy informacje o oczekiwaniach skierowanych przez otoczenie względem pozycji, jaką zajmuje. Jest ona „(...) zbiorem społecznie i kulturowo zdefiniowanych oczekiwań, które jednostki mają spełniać w określonych sytuacjach społecznych. Jest ona określana przez społeczeństwo, przypisana każdej jednostce w obrębie kategorii, a przez nie przyuczana i wyuczana" (Mandal, 2004: 22). Role społeczne (płciowe) obejmują charakterystyczne oczekiwania reprezentatywne dla danej płci.

Płeć, mimo że nie jest rozumiana tylko jako kategoria biologiczna, ale i społeczna, to, jak wynika z powyższych analiz, wprowadza rozróżnienie między płcią a rodzajem. Płeć oznacza występowanie różnic anatomicznych umożliwiających prokreację, natomiast rodzaj jest efektem kulturowej i społecznej konstrukcji płci. Na kanwie tych rozważań prezentowane będą wyniki badań obejmujące płeć psychologiczną i wsparcie otrzymywane przez kobiety i mężczyzn. Wsparcie jest rozumiane jako otrzymywana faktycznie pomoc. Jest ono oceniane subiektywnie przez podmiot.

\section{Materiał i metody badań}

Celem przeprowadzonych badań było określenie płci psychologicznej współczesnych kobiet i mężczyzn na tle spostrzeganego wsparcia. Skoncentrowano się na jednym problemie badawczym, wynikającym z tak postawionego celu: Czy, a jeśli 
tak, to jak płeć psychologiczna różnicuje wsparcie u kobiet i mężczyzn? Badanie przeprowadzono metodą sondażu diagnostycznego i techniką ankiety z wykorzystaniem kwestionariusza. W badaniach posłużono się zmodyfikowanym kwestionariuszem wsparcia M. Kazimierczak, M. Plopy (2007) oraz Inwentarzem do oceny płci psychologicznej IPP w opracowaniu A. Kuczyńskiej.

W celu zebrania materiału badawczego wykorzystano metody doboru nielosowego - czyli metodę nieprobabilistyczną kuli śnieżnej oraz dobór celowy. Metoda kuli śnieżnej przydatna jest w badaniach grup społecznych, które mogą być dla badacza trudno dostępne. W omawianym projekcie grupę tę stanowiły żony żołnierzy zawodowych wyjeżdżających na misje stabilizacyjne oraz żony żołnierzy, którzy wykonują obowiązki służbowe w kraju. Największą grupą kobiet - żon żołnierzy zawodowych stanowiły matki dzieci uczęszczających do przedszkola. Dobór celowy wykorzystano do zebrania materiału badawczego od żołnierzy zawodowych. Dobór celowy jest związany z uzyskaniem zgody od Podsekretarza Stanu Ministerstwa Obrony Narodowej. Na dwukrotne przeprowadzenie badań uzyskano zgodę MON i jednostek wojskowych. Badania przeprowadzono na przełomie 2011 i 2012 roku oraz w roku 2013.

Respondentki poproszono o wypełnienie Inwentarza do oceny płci psychologicznej (IPP). Przeprowadzone dotychczas badania empiryczne wskazują istotny wpływ płci psychologicznej na funkcjonowanie jednostki, możliwość jej rozwoju i konstruktywnego działania (Kuczyńska, 1992: 5). Istnieją cztery główne konfiguracje cech psychologicznych związanych z płcią, odpowiadające następującym typom płci psychologicznej: 1) osoby określane seksualnie (sex-typed), charakteryzujące się cechami psychicznymi odpowiadającymi ich płci biologicznej; 2) osoby androgyniczne, charakteryzujące się jednocześnie cechami kobiecymi, jak i męskimi, niezależnie od swojej płci biologicznej (Lelakowska, Zdrojewicz, 2008: 15); 3) osoby nieokreślone seksualnie; mają one w niewielkim stopniu ukształtowane cechy kobiece i męskie (niezależnie od swojej płci biologicznej); 4) osoby krzyżowo określone seksualnie, charakteryzujące się cechami psychicznymi odpowiadającymi przeciwnej płci niż ich płeć biologiczna (Kuczyńska, 1992: 5). Normalizacja narzędzia przeprowadzona była ponad 20 lat temu, dlatego w literaturze wskazuje się na konieczność weryfikacji cech przynależnych do poszczególnych skal (Konopka, Frączak, 2013: 71). Niemniej w analizowanych badaniach posłużono się narzędziem bez modyfikacji cech przynależnych do poszczególnych skal.

Kwestionariusz wsparcia spostrzeganego został przygotowany $\mathrm{w}$ oparciu o Kwestionariusz Komunikacji Małżeńskiej w opracowaniu M. Kazimierczak i M. Plopy. Przygotowano tylko pytania dotyczące wsparcia. Pozostałe dwie skale - zaangażowanie i deprecjację - odrzucono ze względu na charakter podjętych badań. Kwestionariusz może być stosowany zarówno w badaniach par małżeń- 
skich, jak i osób indywidualnych. W niniejszych badaniach będzie rozpatrywane wsparcie ze strony rodziny spostrzegane przez badanego. Skala wsparcia zawiera 11 twierdzeń, do których respondent ustosunkowuje się poprzez wybór jednej z pięciu kategorii odpowiedzi: 1 - nigdy; 2 - rzadko, 3 - czasami, 4 - często, 5 - zawsze. Suma punktów uzyskanych w ramach skali stanowi wynik surowy, który jest podstawą określenia poziomu wsparcia (Plopa, 2007: 145-146).

Badania przeprowadzono wśród 930 kobiet i mężczyzn. Po zebraniu materiału badawczego do analizy zakwalifikowano 503 kwestionariusze wypełnione przez respondentów. Pierwszym kryterium analizy były ankiety wypełnione przez osoby będące w związku małżeńskim. Drugim kryterium to zatrudnienie mężczyzn w określonym zawodzie. Kobiety są żonami żołnierzy zawodowych, natomiast mężczyźni są zatrudnieni w Polskich Siłach Zbrojnych. Zgromadzono 149 ankiet kobiet - żon żołnierzy zawodowych. Wśród mężatek wyróżniono dwie grupy ankietowanych. Pierwsza - to żony żołnierzy wyjeżdżających na misje (94); druga - żony żołnierzy pozostających w kraju (55). Kobiety są reprezentantkami dwóch okresów rozwojowych: wczesnej dorosłości oraz środkowego okresu dorosłości. Pomiędzy kobietami w kategorii wieku nie ma znaczących różnic. Wykształcenie kobiet analizowano na czterech poziomach w odniesieniu do żon żołnierzy zawodowych. Szkołę zawodową ukończyło 2,79\% kobiet, szkołę średnią odpowiednio do podanej kolejności $24,48 \%$ respondentek. Dyplom studiów zawodowych otrzymało 23,08\% mężatek. Natomiast studia magisterskie ukończyło 48,95\% ankietowanych. Żony żołnierzy zawodowych rzadziej legitymują się wykształceniem zawodowym i średnim, a częściej posiadają dyplom studiów zawodowych lub magisterskich. Respondentki uczestniczące w badaniach zamieszkiwały duże aglomeracje miejskie.

Grupa mężczyzn to 354 żonatych żołnierzy zawodowych. Wśród nich 152 osoby wyjeżdżały na misje pokojowe, a 202 mężczyzn pełni służbę zawodową w kraju. Największa liczba respondentów to osoby wczesnego okresu dorosłości do 34. roku życia (50,68\%). Natomiast środkowy okres dorosłości reprezentowało $49,32 \%$ żołnierzy. W przeprowadzonych badaniach 14,08\% respondentów ukończyło szkołę zawodową, $61,8 \%$ żołnierzy legitymuje się wykształceniem średnim, $11,49 \%$ ukończyło studia zawodowe, a 10,63\% otrzymało tytuł magistra. Porównanie grupy kobiet i mężczyzn prowadzi do wniosku, że obie grupy reprezentują osoby będące $\mathrm{w}$ dwóch okresach rozwojowych: wczesnej i średniej dorosłości. Biorąc pod uwagę wykształcenie, okazuje się, że kobiety częściej legitymują się wykształceniem wyższym zawodowym i magisterskim, natomiast mężczyźni częściej posiadają wykształcenie średnie. W Polskich Siłach Zbrojnych obecnie zatrudniani są mężczyźni na stanowisku zawodowego szeregowego, które zastępuje obowiązkowy nabór do służby zasadniczej. Korpus szeregowych zawodowych to nowy korpus stworzony w celu uzawodowienia stanowisk, które do tej 
pory przysługiwały poborowym. Żołnierze z korpusu szeregowych są zatrudniani na stanowiskach młodszych specjalistów, kierowców, strzelców, kucharzy (Maciejewski, 2009: 25). „Stanowiska służbowe w strukturach armii są związane ze strukturą stratyfikacyjną, inaczej hierarchiczno-prestiżową, złożoną $\mathrm{z}$ wielu warstw powiązanych hierarchicznie. Warstwy te, tworząc hierarchie, określają względnie trwałe dystanse pomiędzy sobą jako kategoriami struktury zawodowej” (Chojnacki, 2008 za: Maciejewski 2009, s. 25). Najniższą warstwę stanowi korpus szeregowców. Analiza w zakresie wieku, wykształcenia mężczyzn oraz posiadanego stopnia służbowego wskazuje, że chcąc uzyskać awans, muszą się dokształcać. Żołnierze, pełniąc służbę kontraktową w Polskich Siłach Zbrojnych, mogą liczyć na awans i mają stworzone możliwości do nauki.

\section{Wyniki badań}

W analizie statystycznej materiału badawczego ustalono następujące wskaźniki: rozkłady liczebności, średnią arytmetyczną $(\mathrm{M})$, odchylenie standardowe (SD), istotności różnic między grupami na podstawie ANOVA Kruskala-Wallisa oraz Test U Manna-Whitneya. Siłę związków badano współczynnikiem korelacji rang Spearmana. Badano również różnice w sile związku pomiędzy grupami, za statystycznie istotne przyjęto wyniki spełniające warunek $\mathrm{p}<0,05$.

W wyniku analizy zebranych danych stwierdzono, że niewielka liczba jest kobiecych mężczyzn, czyli osób o przewadze cech kobiecych $\left(\dot{Z} \mathrm{M}^{1}=5,43 \%\right.$; $\dot{Z} \mathrm{~K}=4,25 \%)$. Następną małą grupą są osoby nieokreślone seksualnie, $\mathrm{z}$ zaznaczeniem, że jest ich więcej wśród osób pozostających w kraju (ŻM = 13,95\%; $\dot{Z} \mathrm{~K}=18,56 \%$ ). Męscy mężczyźni stanowią 17,83\% badanej grupy żołnierzy z misji stabilizacyjnych (ŻK=19,76\%). Ponad $62,79 \%$ badanych żołnierzy z doświadczeniami misji pokojowych i 57,49\% żołnierzy pozostających w kraju odznacza się cechami androgynicznymi. Celem przedstawienia kobiecości i męskości w grupie respondentów przeanalizowano odpowiedzi w aspektach: kobiecość i męskość. Żołnierze wyjeżdżający na misje wojskowe charakteryzują się kobiecością, której wynik wynosi $M=54,399(S D=7,16)$ i męskością $M=54,603(7,63)$. Natomiast żołnierze pozostający $\mathrm{w}$ kraju cechują się kobiecością równą $\mathrm{M}=53,11(\mathrm{SD}=6,53)$ i męskością $\mathrm{M}=53,8(\mathrm{SD}=6,61)$. Różnice między grupami są nieistotne, ale przy mniejszym odchyleniu standardowym w grupie żołnierzy pozostających $\mathrm{w}$ kraju. Prezentowane $\mathrm{w}$ niniejszym artykule badania

\footnotetext{
${ }^{1} \mathrm{~W}$ artykule zastosowywano skrót odnoszący się do żołnierzy wyjeżdżających na misje - ŻM oraz żołnierzy wykonujących obowiązki zawodowe w kraju - ŻK.
} 
w porównaniu do badań z 2012 roku potwierdzają występowanie w grupie mężczyzn najczęściej androgynii (Molesztak, 2013).

Rozkład płci psychologicznej prowadzi do wniosku, że wśród współczesnych kobiet występują osoby charakteryzujące się podobnie jak mężczyźni - androgynią. Androgyna występuje wśród 55,06\% żon żołnierzy wyjeżdżających na misje i 58,33\% kobiet, których mężowie wykonują obowiązki służbowe w kraju. Różnica pomiędzy kobietami wynosi 3\%. W oparciu o wyniki badań można stwierdzić, że większa rozbieżność występuje w kategorii płci określanej jako kobiece kobiety. Wynika $\mathrm{z}$ nich, że grupa żon żołnierzy wyjeżdżających na misje określanych jako kobiece kobiety jest mniejsza niż w grupie kobiet, których mężowie pracują w kraju. Codzienne relacje małżonków nie pozostają bez znaczenia w zachowaniu się kobiet. Obecność partnera życiowego skłania częściej kobiety do działań stereotypowo im przypisanych. Dane z badań wskazują jednocześnie, że w grupie kobiet w okresie czasowego rozstania z mężem częściej występują osoby definiowane jako nieokreślone seksualnie i męskie niż w grupie żon, których mężowie żołnierze wykonują pracę w kraju. Zauważyć można, że kobiety - żony, których mężowie wyjechali z kraju, charakteryzują się rzadziej cechami kobiecymi niż grupa żon, których mężowie pracują w kraju. W celu stwierdzenia, czy wyniki badań są charakterystyczne dla tej grupy kobiet, porównano je $\mathrm{z}$ badaniami kobiet, których mężowie są zatrudnieni w różnych zakładach pracy w miejscu zamieszkania. Okazuje się, że jest to grupa charakteryzująca się, podobnie jak poprzednie, najczęściej androgynią. Jest ich jednak procentowo mniej niż w małżeństwach żołnierskich. W grupie porównawczej kobiet występują kobiety o cechach męskich. Zebrane dane podkreślają pewne tendencje, jednak kolejne badania winny wskazać, czy żony żołnierzy wyjeżdżających na misje cechują się określonymi cechami osobowości, które ułatwiają funkcjonowanie w sytuacji nieustannego zagrożenia życia męża. Dla przedstawienia kobiecości i męskości $\mathrm{w}$ grupie respondentek przeanalizowano odpowiedzi, biorąc pod uwagę kobiecość i męskość. Kobiety, których mężowie wyjeżdżają na misje wojskowe, charakteryzują się kobiecością, której wynik wynosi $\mathrm{M}=56,02(\mathrm{SD}=6,51)$ i męskością $\mathrm{M}=50,47$ (9,36). Natomiast kobiety, których mężowie pozostają $\mathrm{w}$ kraju, cechują się kobiecością równą $\mathrm{M}=57,79(\mathrm{SD}=6,07)$ i męskością $\mathrm{M}=52,43(\mathrm{SD}=7,39)$. $\mathrm{W}$ grupie porównawczej kobiet kobiecość osiągnęła wynik średni $\mathrm{M}=56,46$ $(\mathrm{SD}=6,24)$, a męskość $\mathrm{M}=49,10 \quad(\mathrm{SD}=7,89)$. Cechy męskości są najniższe w grupie porównawczej kobiet. Na uwagę zasługuje fakt, że średnia jest najwyższa u kobiet, których mężowie - żołnierze są w kraju. Druga uwaga odnosi się do odchylenia standardowego, które w każdej grupie jest wyższe w wynikach cech męskości.

Płeć psychologiczną analizowano na tle wsparcia spostrzeganego przez ankietowanych. W grupie mężczyzn okazało się, że poziom wysoki wsparcia wystę- 
puje blisko u 1/3 ankietowanych i jest najwyższy w grupie osób wyjeżdżających na misje wojskowe. Rodzina, świadoma zagrożenia życia, jakie występuje podczas wykonywania obowiązków, wspiera respondentów. Zainteresowanie budzi fakt, że tylko u $12,77 \%$ żon żołnierzy tej grupy występuje wysoki poziom wsparcia. Dwukrotnie więcej kobiet określa wsparcie na niskim poziomie. Wyniki wskazują, że wsparcie niskie częściej występuje u respondentów niż wysokie. W celu dokładnej analizy podjętego zagadnienia poczyniono kolejne analizy statystyczne. Dane dotyczące poziomu wsparcia na tle płci psychologicznej zawiera tabela 1. Korelacje są istotne z p $<0,05$

Tabela 1. Poziom wsparcia a płeć psychologiczna ankietowanych. Źródło: badania własne

\begin{tabular}{|l|l|l|}
\hline \multicolumn{1}{|c|}{ Wsparcie } & \multicolumn{1}{c|}{ Kobiecość } & \multicolumn{1}{c|}{ Męskość } \\
\hline Kobiety - mąż na misji & $0,2793 \mathrm{p}=0,008$ & $0,5138 \mathrm{p}=0,0001$ \\
\hline Kobiety - praca w kraju & $0,4087 \mathrm{p}=0,005$ & $0,2394 \mathrm{p}=0,113$ \\
\hline Żołnierze - praca na misji & $0,3295 \mathrm{p}=0,0001$ & $0,1953 \mathrm{p}=0,027$ \\
\hline Żołnierze - praca w kraju & $0,2064 \mathrm{p}=0,007$ & $0,2450 \mathrm{p}=0,001$ \\
\hline
\end{tabular}

Analiza korelacji wsparcia i płci psychologicznej we wszystkich grupach prowadzi do wniosku, iż kobiety, których mężowie przebywają na misjach stabilizacyjnych, charakteryzują się wysokim związkiem z męskością, a niskim z kobiecością. Może to świadczyć o tym, że sytuacja, w jakiej się znajdują, zmusza je do podejmowania działań niestereotypowych. Nieobecność współmałżonka powoduje przejmowanie przez kobiety obowiązków mężczyzny. Inna specyfika życia rodzinnego występuje w małżeństwach bez czasowego rozstania. Świadczą o tym kolejne wyniki. Kobiety, których mężowie wykonują obowiązki służbowe w jednostkach w kraju, charakteryzują się przeciętnym związkiem z kobiecością, a niskim z męskością. Zgromadzone dane dotyczące grupy mężczyzn nie są zróżnicowane. Żołnierze wyjeżdżający na misje cechują się przeciętnym związkiem wsparcia $\mathrm{z}$ kobiecością i niskim z męskością. Natomiast żołnierze pracujący $\mathrm{w}$ jednostkach wojskowych $\mathrm{w}$ kraju przedstawiają niski związek z kobiecością i męskością. Z przedstawionych wyników badań wynika, że płeć psychologiczna ma wyższe znaczenie, gdy żołnierz wyjeżdża na misję stabilizacyjną. Mężczyźni doznają go więcej (albo oceniają wyżej), gdy są bardziej kobiecy, a kobiety, gdy są bardziej męskie.

Otrzymane dane empiryczne sugerują, że respondenci w większości reprezentują typ androgyniczny. Androgynia w kulturze polega na intencjonalnym zacieraniu różnic kulturowych między kobietami a mężczyznami. Psychologiczna 
androgynia oznacza integrację i komplementarność w osobowości pierwiastka męskiego i kobiecego. Osoby androgyniczne wykazują się dużą elastycznością form reagowania i bogatszym repertuarem zachowań. Większość respondentów charakteryzuje się dużą płynnością zachowania i wrażliwością wobec zewnętrznych wymagań. Szczególne znaczenie ma to zachowanie w sytuacji nieobecności współmałżonka - zarówno męża przebywającego na misji wojskowej, jak i żony dla żołnierza. Literatura naukowa wskazuje, że osoby androgyniczne mają pozytywny obraz siebie, wyższą samoocenę i silniejszą osobowość. Dlatego też pozwala to przypuszczać, że takie osoby dysponują szerszym repertuarem zachowań oraz lepiej organizują informacje w zakresie wymiaru płci (Lelakowska, Zdrojewicz, 2008: 14-20). Współcześnie w literaturze stwierdza się znaczący wzrost liczby osób androgynicznych. Świadczy to między innymi o „osłabieniu dualizmu ról płci i funkcjonowania jednostek w sytuacji dostępności różnorodnych wzorców kobiecości i męskości” (Izdebski, Paprzycka, Mianowska, 2014: 22). Na świecie prowadzone są eksperymenty w zakresie stereotypów poprzez wprowadzanie różnych zmiennych. Stwierdzono na przykład, że możliwość wystąpienia stereotypów jest mniejsza, gdy badani formułują sądy proste niż złożone. Jeśli sytuacje odnoszą się do konkretnych osób, problemów jednostki posługują się częściej jasnymi kryteriami, co przynosi efekt porzucania stereotypów. Dwuznaczność i zawiłość sprzyja posługiwaniu się stereotypami (za: ChomczyńskaRubacha, 2006: 113). Można wnioskować, że respondenci, którzy posługują się jasnymi kryteriami w ocenie i mają na uwadze swoje działania, oceniają je obiektywnie.

Zadania pojawiające się przed jednostką $\mathrm{w}$ określonej sytuacji powodują spostrzeganie pewnego fragmentu tej sytuacji z punktu widzenia wizji odmiennej i bardziej pożądanej. Świadomość istoty sytuacji i sprecyzowanego zadania postawiły jednostki wobec nieznanego dotąd obszaru działań. Wykonywanie zadań nieobjętych dotychczasowym repertuarem zachowań zgodnych z płcią wymusiły podejmowanie ról społecznych nieprzewidzianych tradycyjnie dla płci. Współczesna rzeczywistość, wskazująca na konieczność pogodzenia pracy zawodowej z życiem rodzinnym, realizację samotnego rodzicielstwa, niedostatek zasobów materialnych czy też realizację własnych wizji przyszłości, ambicji, aspiracji powoduje zmianę tradycyjnych zadań przysługujących kobietom i mężczyznom.

\section{Konkluzje}

Na zmianę ról społecznych kobiet i mężczyzn należy patrzeć wielowątkowo. Jednym z ważnych obszarów jest zmiana społecznej roli kobiet w kontekście równości płci i jej znaczenia dla prokreacji. Niezbędne jest także przygotowanie rozwią- 
zań dotyczących łączenia dwóch ważnych aktywności - zawodowej i rodzinnej przez kobiety i mężczyzn (Kotowska, Jóźwiak 2011). Zmiana ról podyktowana jest oczekiwaniami społeczeństwa wobec kobiet i mężczyzn. Zadania stojące przed jednostką prowadzą do poszukania rozwiązania, które będzie satysfakcjonujące zarówno dla samej jednostki i jej rodziny oraz zakładu pracy. Wyzwania cywilizacyjne pozwalające kobietom na pracę zawodową, karierę, realizację własnych aspiracji stały się przyczynkiem do podjęcia ról przysługujących kulturowo mężczyznom. Różnice pomiędzy kobietami i mężczyznami $\mathrm{w}$ aspekcie ilościowym są nieistotne. „Najnowsze badania pokazują, że wielkość różnic zależy bardziej od zmiennych indywidualnych takich jak: poziom inteligencji, wykształcenie, kierunek studiów, zainteresowania, akceptacja stereotypów płciowych, a mniej związana jest z płcią (...)" (Mandal, 2003: 156).

Sytuacja kobiet, których mężowie pracują poza miejscem zamieszkania, wymaga od nich nieustannej modyfikacji w wypełnianiu ról. Podobnie nieobecność kobiet również ma znaczenie dla partnerów. W tych sytuacjach kształtują się relacje korygujące tradycyjne zachowania partnerów. Innym problem jest kwestia procesu dostosowywania się do siebie po rozłące i procesu przygotowującego do czasowego oddalenia się. $\mathrm{Z}$ uwagi na fakt nieustannie zwiększającej się liczby związków będących w czasowej rozłące zagadnienie to wymaga dalszych badań.

\section{Literatura}

Bem S.L. (1974). The measurement of psychological androgyny. „Journal of Consulting and Clinical Psychology" Vol 42, s. 155-162.

Bem S.L. (1977). On the utility of alternative procedures for assessing psychological androgyny. „Journal of Consulting and Clinical Psychology" Vol 45, No. 2, s. 196-205.

Bem S.L. (1981). Gender schema theory. A cognitive account of sex typing. „Psychological Review” Vol. 88,4 , s. 354-364.

Bem S.L. (2000). Męskość Kobiecość. O różnicach wynikających z płci, tłum. S. Pikiel. Gdańsk.

Chojnacki W. (2005). Kadra zawodowa Wojska Polskiego $w$ procesie zmian instytucjonalno-organizacyjnych i społecznych. Warszawa.

Chojnacki W. (2008). Profesjonalizacja wojska w teorii i badaniach socjologicznych. Warszawa.

Chomczyńska-Rubacha M. (2006). Wpływ działań edukacyjnych na spostrzeganie stereotypów płciowych. [W:] M. Chomczyńska-Rubacha (red.). Role płciowe. Kultura i edukacja. Łódź.

Dulko S. (2003). ABC płci. „KOSMOS. Problemy Nauk Biologicznych” t. 52, nr 1, s. 5-10.

Gawrycka M., Wasilczuk J., Zwiech P. (2011). Szklany sufit i ruchome schody kobiety na rynku pracy. Warszawa.

Izdebski Z., Paprzycka E., Mianowska E. (2014). Płeć biologiczna i płeć społeczno-kulturowa a związki intymne Polaków. „Studia Socjologiczne” 4 (215), s. 13-39.

Konopka K., Frączak A. (2013). Płeć psychologiczna a gotowość do agresji interpersonalnej u kobiet i mężczyzn. „Polskie Forum Psychologiczne” t. 18, nr 1, s. 65-80. 
Kotowska I.E., Jóźwiak J. (2011). Panelowe badanie przemian relacji między pokoleniami, $w$ rodzinie oraz między kobietami i mężczyznami: generacje, rodziny i płeć kulturowa - GGS-PL. „Studia Demograficzne" 1(159), s. 99-106.

Kuczyńska A. (1992), Inwentarz do oceny płci psychologicznej. Warszawa.

Lelakowska K., Zdrojewicz Z. (2008). Płeć psychologiczna a preferowane bodźce seksualne. „Seksuologia Polska" 6, 1, s. 14-20.

Machel H. (2012). Wstęp. [W:] A. Chybicka, N. Kosakowska-Berezecka, P. Pawlicka (red.). Podróże między kobiecością i męskością. Kraków.

Maciejewski J. (2009). Zawodowy szeregowy w Wojsku Polskim - sukces czy porażka? Zawód profesjonalizacja i kariera. [W:] J. Maciejewski, A. Krasowska-Marut, A. Rusak (red.). Szeregowcy $w$ grupach dyspozycyjnych. Socjologiczna analiza zawodu i jego roli w społeczeństwie. Wrocław.

Mandal E. (1994). Businesswoman - nowy wzorzec kobiecości. Kobieta i Biznes: akademicko-gospodarcze forum, 1994, t. $2 \mathrm{nr} 4$. Warszawa.

Mandal E. (2003). Kobiecość i męskość. Popularne opinie a badania naukowe. Warszawa.

Mead M. (1987). Kultura i tożsamość, tłum. J. Hołówka. Warszawa.

Molesztak A. (2013). Married life happiness of soldiers returning from peace-keeping missions. [W:] M. Bargel, E. Jarosz, M. Jůzl (ed). Sociálni pedagogika v kontextu životnich etap človåěka. Brno.

Pankowska D. (2005). Wychowanie a role płciowe. Gdańsk.

Pankowska D., Chomczyńska-Rubacha M. (2014). Wyznaczniki tożsamości młodych kobiet i mężczyzn w percepcji studentek $i$ studentów. Wykład wygłoszony podczas Interdyscyplinarnej Konferencji Naukowej: „Kobiety i mężczyźni w postmodernistycznym świecie” 9 kwietnia 2014.

Plopa M. (2007). Więzi w matżeństwie i rodzinie. Metody badań. Kraków.

Sanocka K. (2012). Stereotypy płci w czytankach - wybrane przykłady zmian zachodzacych $w$ polskich szkołach. „PALIMSEST. Czasopismo Socjologiczne” nr 3, www.palimpsest.socjologia.uj. edu.pl, dostęp: 26.06.2014.

Schaffer R.H. (2009). Psychologia dziecka, tłum. A. Wojciechowski. Warszawa.

Wojciszke B. (2009). Kobieta zmienna jest. Gdańsk.

Zimbardo P. (2004). Psychologia i życie, tłum. E. Czerniawska. Warszawa. 